\title{
Comparitive histological and ultrastructural studies on the stomach of African cat fish (Clarias gariepinus) and (Oreochromis niloticus)
}

Mona Mohammed Mostafa Elwan ${ }^{1 *}$ and Eman El Sayed Mohammed El Nahass ${ }^{2}$

*Correspondence: Monaelwan287@yahoo.com

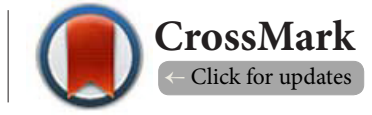

'Lecturer of Cytology and Histology, Zoology department, Faculty of science, Tanta university, Egypt.

${ }^{2}$ Lecturer of Comparitive Anatomy of Vertebrates, Zoology department, Faculty of science, Tanta university, Egypt.

\begin{abstract}
This study aims to illustrate the morphological, histological and ultrastructural differences in the stomach of a carnivorous fish, Clarias gariepinus and an herbivorous fish Oreochromis niloticus in correlation with their feeding habits .Twenty live O. niloticus and C. gariepinus were collected from Nile River. After capture, they were capitated; the entire digestive tract was removed from the body. The stomach was separated and then cut into three parts; the cardiac region was separated and examined. The histological characterizations revealed that the wall of the stomach in both species is composed of four layers. The tunica mucosa of $O$. niloticusis was thrown up into several broad folds which is lined with high columnar mucous-secreting cells with homogenous faintly stained cytoplasm and basal oval nuclei, large mucous glands were noticed and gastric pits appeared short and shallow in depth while the mucosa layer of $C$. gariepinus characterized by absence of mucous glands among its epithelial cells and gastric pit is deep and wide. The muscularis layer is thicker in C. gariepinus compared to O. niloticus. TEM of the mucosa layer of the stomach of both species revealed that oxyntic cell that exhibits tubulovesicular system with microvilli and mucous neck cells with extensive masses of mucous secretions, entero-endocrine cells that characterized by electron dense granules.Finally we concluded that there are differences between two studied species according to their feeding habits.
\end{abstract}

Keywords: Histology- TEM- Oreochromis niloticus- Clarias gariepinus

\section{Introduction}

The structure and functional characteristics of gastrointestinal tract of fish vary widely among species and seem to a great extent to match the wide diversity of feeding habits and environmental conditions exploid by fish [1].

Depending on feeding habits and diet, fish are generally classified as carnivorous (eating fish and large invertebrates), herbivorous (consuming mainly plant material), omnivorous (consuming a mixed diet) and detritivorous (feeding largerly on detritus) [2-4].

Study of anatomy, histology and histochemistry provide information for the characterization of the digestive tract to understand the physiology, feeding habits and management of fish species [5].

The stomach of fishes is classified into many categories de- pending on their characteristic shapes; (1) J-shape in African and American catfish; (2) straight with enlarged lumen in pike; (3) channel catfish and halibut; (4) U-shaped in salmonide; and (5) Y-shaped in tilapia [6].

Shape of the teleostean stomach is variable; it may be rectilinear as in Esox amerieanus and Esox lucius or siphonal as in Ambloplites rupestris, Lepomis maerochirus and Pomoxis nigromaculatus or caecal as in Ictalurus nebulosus, Mieropterus salmoides and Pereajlaveseens. The rectilinear and caecal types are associated with piscivorous species [7].

African catfish (C. gariepinus) is widely distributed in Africa and parts of Asia (Syria and South Turkey), its digestive tract characterized by the presence of a large stomach and a short intestine, stomach is J-shaped sac divided into three regions: cardiac, fundic and pyloric [8]. Histologically, the stomach wall 
composed of four tunics: mucosa, submucosa, muscularis externa and serosa. Mucosa showed thick longitudinal folds which lined with simple high columnar cells containing oval basally located nuclei, these cells contained apical located mucosubstances that reacted positively with Periodic-acid Schiff and negatively with Alcian blue stains.

[9] observed that only the cardiac and fundic regions contained mucosal glands. The fundic glands were lined with oxynticopeptic cells. Enteroendocrine cells were distributed in the gastric wall within the epithelial cells of the gastric mucosa and gland.

[6] studied the digestive tract of O. niloticus and described it as a region with tubular glands composed of large mucous cells continuous from the entry of the esophagus, across the anterior part of the stomach to the pyloric valve providing a bypass circumventing the sac-like portion of the stomach, this region lined with striated muscle may be a means of disposing of unwanted material by regurgitating it or by passing it rapidly along to the intestine. Large mucus cells in the tubular glands and the neck cells of the gastric glands probably protect the mucosa from the very acid contents of the stomach.

The principle goal of this work is illustrating the morphological, histological and ultrastructural differences in the stomach of a carnivorous fish, Clarias gariepinus and an herbivorous fish Oreochromis niloticus in correlation with their feeding habits.

\section{Material and methods \\ Material}

Twenty live, apparently normal and healthy (O niloticus) and (C. gariepinus) were collected from Nile River. After capture, they were killed by capitation; the entire digestive tract was removed from the body. The stomach was separated and cut into three parts, the cardiac region of the stomach was separated and examined.

\section{Methods \\ Histological Examination}

Small pieces of stomach were immediately fixed in Bouin's fluid and $10 \%$ neutral buffered formalin for 24 hours. The tissue samples were dehydrated in ascending grades of ethyl alcohol, cleared by xylene and embedded in paraffin. Sections of $5 \mu$ thickness were mounted and stained with Haematoxylin and Eosin method [10]. All preparations were microscpically examined for the histological examination.

\section{Transmission Electron Microscopy}

For transmission electron microscopy, small pieces of $1 \times 1$ $\mathrm{x} 1 \mathrm{~mm}$ of stomach tissues were obtained and were rapidly processed according to protocol of EM unit, Faculty of Medicine, Tanta University.

\section{Results}

\section{Gross morphology}

The stomach of the Clarias gariepinus appeared as a curved muscular sac, located in dorsocranial region of the peritoneal cavity behind the liver. It extended from the oesophagus to intestine. The stomach of catfish was J- shaped with the ascending limb ended at the end of pyloric region. It attained its greatest diameter about the middle of its length, posterior to which it became more slender especially near the pyloric end. The stomach was divided into three regions; cardiac region: an initial region that was close to the entry point of the oesophagus. Fundic region: was the large sac- shaped blind middle region, which communicated with the other two regions of the stomach. Pyloric region: was the terminal small region. The end of the pyloric region extended towards the beginning of the intestinal tube (Figure 1a).

On the other hand the stomach of Oreochromis niloticus is small and sac like structure and divided into two portions as follows: cardiofundic and pyloric portions as well as it is separated from the intestine by pyloric sphincter (Figure 1b).

\section{Microscopical examination \\ Light microscopy}

The cardiac region of the stomach composed of four distinct concentric tunics arranged from inward to out-ward as follows: mucosa; submucosa; muscularis externa; and serosa. The tunica mucosa was thrown up into several broad folds or rughae. These folds appeared as cup-shaped folds of different sizes including the lining surface epithelium and the underlying lamina propria (Figure 2a). Its mucosa was lined with high columnar mucous-secreting cells with homogenous faintly stained cytoplasm and basal oval nuclei and interrupted large mucous glands. Gastric pits were formed by invaginations of the mucosal layer into the underlying lamina propria and continuous with the openings of the gastric glands. These pits appeared short and shallow in depth, lined with tall columnar cells representing a continuation of the surface epithelial cells. The lamina propria extending deeply in the

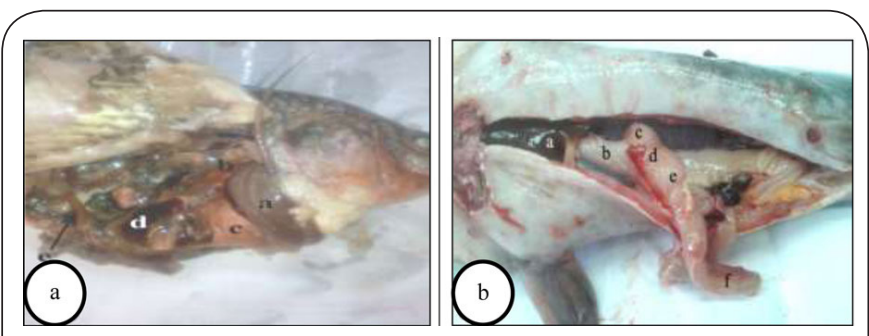

Figure 1(a,b): Gross morphology of the stomach of Nile Oreochromis niloticus and Clarias gariepinus Figure 1a) Photograph of the dissected Nile Oreochromis niloticus showing stomach that consists of cardiac portion (a) and pyloric portion (b), liver (c), spleen (d), proximal part of the intestine (e). Figure 1b) Ventral view of Clarias gariepinus showing the relationship of the gastrointestinal tract with other organs in the abdominal cavity. Oesophagus (b) connected to pharynx and stomach. Stomach is divided into three portions cardiac (c), fundus (d) and pyloric (e) which overlapped by the liver (a). Notice the few convolutions of the intestine (f). 


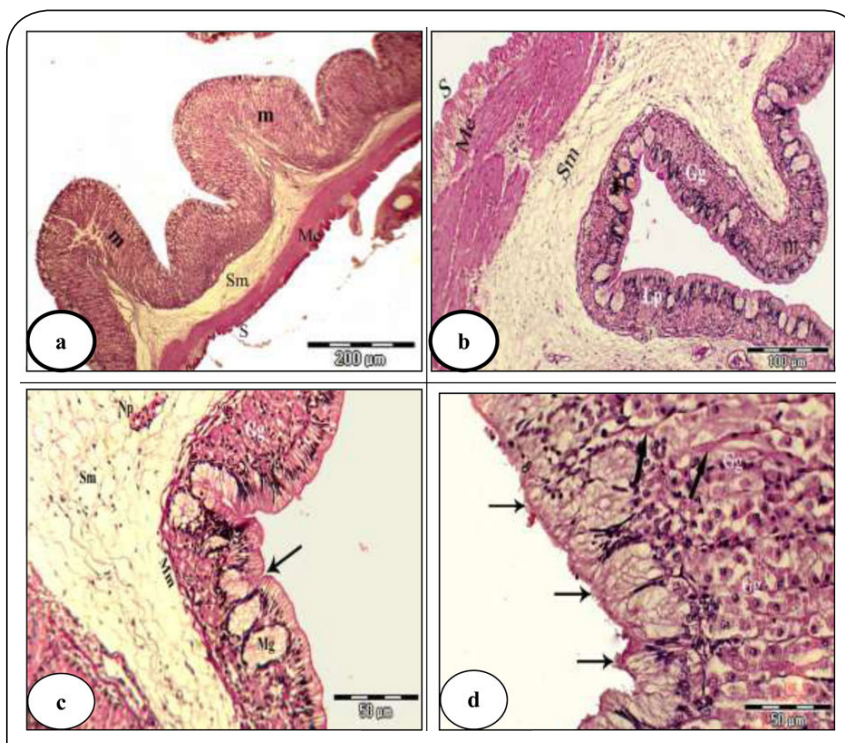

Figure 2(a-d): Cross sections of the cardiac stomach of Oreochromis niloticus showing: 2a) four distinct layers ; dome shape folds or rughae of mucosa (M), thick layer of submucosa $(\mathrm{Sm})$, thin layer of muscularis externa $(\mathrm{Me})$ arranged inner circular and outer longitudinal smooth muscle fibers and serosa (S) (X 100). Figure 2b) High magnified part of (a) exhibits folded mucosa (m) with lining epithelium and lamina propria (Lp), gastric glands (Gg), thick layer of submucosa $(\mathrm{Sm})$, muscularis externa $(\mathrm{Me})$ and thin serosal coat (S) (X 200). Figure 2c) showing cup-shaped mucosal folds lined with simple columnar cells with oval basal nuclei, shallow and narrow gastric pits (arrow), plenty of parallel tubular gastric glands $(\mathrm{Gg})$ with cuboidal cells and basal oval nuclei and large mucous glands $(\mathrm{Mg})$, muscularis mucosa $(\mathrm{Mm})$ and submucosa layer with nerve plexus $(\mathrm{Np})$ (X 400). Figure 2d) Cross section of the cardiac region of Oreochromis niloticus showing broad mucosal folds lined with single layer of surface columnar cells with striated brush borders (arrows), plenty of parallel tubular gastric glands $(\mathrm{Gg})$ formed by a single cell type (oxinopeptic cells) with central nuclei. Note the tubular glands permeated by many collagen fibers (thick arrows) (X 400).

core of the mucosal folds contained loose connective tissue with extensive collagen fibers, many blood vessels, and gastric glands (Figures $\mathbf{2} \mathbf{b}$ and $\mathbf{2 d}$ ). These gastric glands appeared as simple tubular parallel glands lined with polyhedral-shaped cells and possessed darkly-stained homogenous cytoplasm containing basally situated oval nuclei. Longitudinally arranged smooth muscle fibers situated in between the lamina propria and the tunica submucosa represented the lamina muscularis mucosae. In addition, diffuse strands of SMF were noticed in the tunica sub-mucosa (Figure $2 \mathrm{c}$ ). The muscularis externa represented by inner circular and outer longitudinal with intermuscular connective tissue containing blood vessels and nerves. Lamina subserosa composed of areolar connective tissue with abundant blood vessels covered with lamina epithelial is serosa composed of mesothelium constituted the tunica serosa of the cardiac region.
Light microscopic observations revealed that the wall of cardiac region of the stomach of Clarias gariepinus was composed of tunica mucosa, tunica submucosa, tunica muscularis and tunica serosa. Cardiac region was thrown into longitudinally oriented cupshaped folds of different sizes. Lamina epithelialis: Surface epithelial cells were high columnar mucosecretory in type with tapering infranuclear region. Migrating cells were seen among the epithelial cells especially in the basal part. No mucous glands were observed between the epithelial cells of cardiac region. Lamina propria: It consisted of loose connective tissue, contained a great number of simple branched tubular gastric glands, which occupied most of the depth of the mucosa and opened into the bottom of each crypt of the mucosal folds (gastric pits). The gastric pits were lined with eosinophilic cylindrical cells, which were shorter than columnar surface cells with basal large oval nucleus, perpendicular to the gastric mucosal surface. Each gland was composed of clusters of polygonal cells called oxyntic-peptic cells, which were radially arranged around a very narrow glandular lumen. These cells had basally located spherical vesicular nuclei. The cardiac glands of catfish resembled the mammalian pancreatic acini.

The tunica submucosa was the thinnest layer when compared with that of the cardiac stomach of Oreochromis niloticus and composed of vascularized loose connective tissue. The tunica musculris externa of the cardiac region was the thickest among the other portions of the stomach. It composed of two layers: outer longitudinal muscle fibers and thick inner circular muscle fibers. A thin serosal layer formed the outer lining of the cardiac stomach, constituted by a thin loose connective tissue lined with a single layer of squamous epithelium (Figure 4d).

\section{Ultrastuctural observations}

Transmission electron microscopic observations of the cardiac Portion of stomach of $O$. nilotica showed that they were lined with number of mucous neck cells with few numbers of mucous granules around the lumen (Figure 4a), mucous neck cell showing nucleus, Golgi apparatus, lymphatic vessel, nerve ending and few numbers of mucous granules; all the previous structures surrounding the lumen (Figure $4 b$ ), surface mucous epithelium appear as columnar cells with apical mucous granules and cell to cell contact (Figure 4c), luminal portion of surface mucous cells showing numerous granules (Figures $\mathbf{4 d}$ and $\mathbf{4 e}$ ) exhibits oxyntic cell that shows large nucleus, prominent nucleolus, large number of active mitochondria with prominent cristae; Note the abundance of tubules of tubulovascular system with extensive microvilli that extend into its lumen, binucleated mucous cell with large number of rough endoplasmic reticulum, smooth endoplasmic reticulum and few number of mucous granules (Figure 4f), the gastric mucosa contained numerous cell comparable to endocrine cells called enteroendocrine cell. This cells were flusk shaped and were characterized by large nucleus, clear cytoplasm and numerous electron dense granules (Figure $\mathbf{4 g}$ ). 


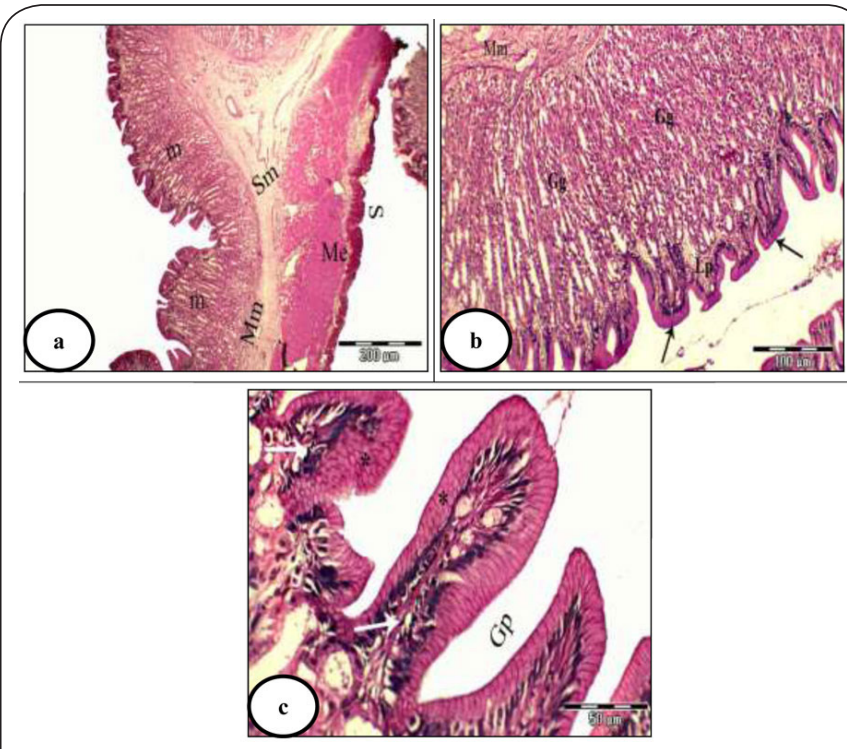

Figure 3(a-c): Cross sections of the cardiac region of stomach of Clarias gariepinus showing: 3a) four distinct layers, cup shaped mucosal folds $(\mathrm{M})$, narrow lamina propria, thin layer of submucosa $(\mathrm{Sm})$, thick layer of muscularis externa (Me) and outer serosa (S) (X 100). Figure $3 \mathbf{b}$ ) showing that the mucosa was thrown into many longitudinal folds (arrows), narrow lamina propria (Lp), gastric glands $(\mathrm{Gg})$, submucosa with diffuse smooth muscle bundles (Mm) (X 200). Figure 3c) Exhibits surface columnar epithelial cells with basal oval nuclei and apical mucin (star), intraepithelial lymphocytes (arrows), deep and wide gastric pit (Gp) (X 400).

On the other hand cardiac Portion of stomach of C. gariepinus showed group of mucous neck cells with extensive masses of mucous secretions around the lumen (Figures $\mathbf{5 a}$, $\mathbf{5 b}$ ) exhibits enteroendocrine cell with electron dense granules of various morphologies, thick layer of muscle and lymphatic vessel in submucosa layer, oxyntic cell that exhibits heterogenous nucleus, large number of oval and round mitochondria, smooth endoplasmic reticulum and extensive extensive tubulovesicular system with microvilli that extend into its lumen are also evident (Figure $5 \mathrm{c}$ ), mucous neck cells with saturated and unsaturated secretory granules with presence of nucleated RBCs in submucosa layer (Figure $5 \mathrm{~d}$ ), mucous neck cell showing nucleus with prominent nucleolus, large number of smooth endoplasmic reticulum and large number of mucous granules (Figure 5e), mucous binucleated cell with prominent nucleoli, mucous granules and large number of rough endoplasmic reticulum and smooth endoplasmic reticulum and mucous secretions (Figure 5f), mucous cell showing mucous granules with large nucleus with prominent nucleolus, number of elongated mitochondria, cisternae of rough endoplasmic reticulum and large number of residual bodies are present (Figure $\mathbf{5 g}$ ).

\section{Discussion}

Our results showed that the stomach of the African catfish appeared J-shaped, similar to that in the South American catfish [11],

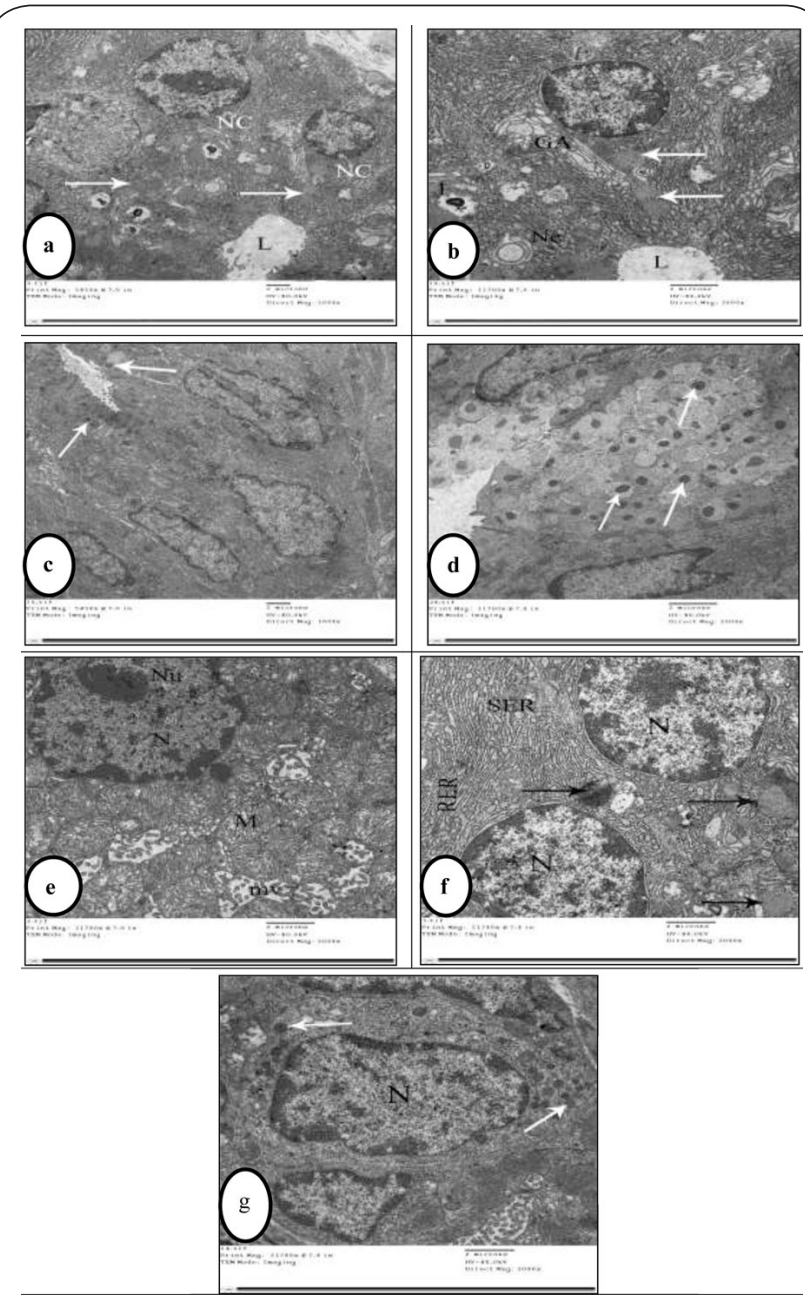

Figure (a-g): Electronmicrographs of stomach of Oreochromis niloticus showing $\mathbf{4 a}$ ) number of mucous neck cells with few numbers of mucous granules (arrows) around the lumen (L). Figure $\mathbf{4 b}$ ) High magnification power of mucous neck cell showing nucleus (N), Golgi apparatus (GA), lymphatic vessel (L), nerve ending ( $\mathrm{Ne}$ ) and few numbers of mucous granules (arrows); all the previous structures surrounding the lumen (L). Figure 4c) showing surface mucous epithelium, the columnar cells and apical mucous granules (arrows). Figure 4d) High magnification power of the luminal portion of surface mucous cells showing numerous granules (arrows). Figure 4e) showing oxyntic cell that exhibits large nucleus $(\mathrm{N})$, prominent nucleolus $(\mathrm{Nu})$, large number of active mitochondria (M) with prominent cristae, tubulovascular system with extensive microvilli (mv) that extend into its lumen. Figure 4f) Exhibits binucleated mucous cell with large number of rough endoplasmic reticulum (RER), smooth endoplasmic reticulum (SER) and few number of mucous granules (arrows). Figure 4g) showing enteroendocrine cell with large nucleus $(\mathrm{N})$, electron dense granules (arrows). channel catfish [12] and rainbow trout [13], this shape may help in extending the duration that food stays in the stomach, thereby ensuring a greater degree of digestion by gastric juice 

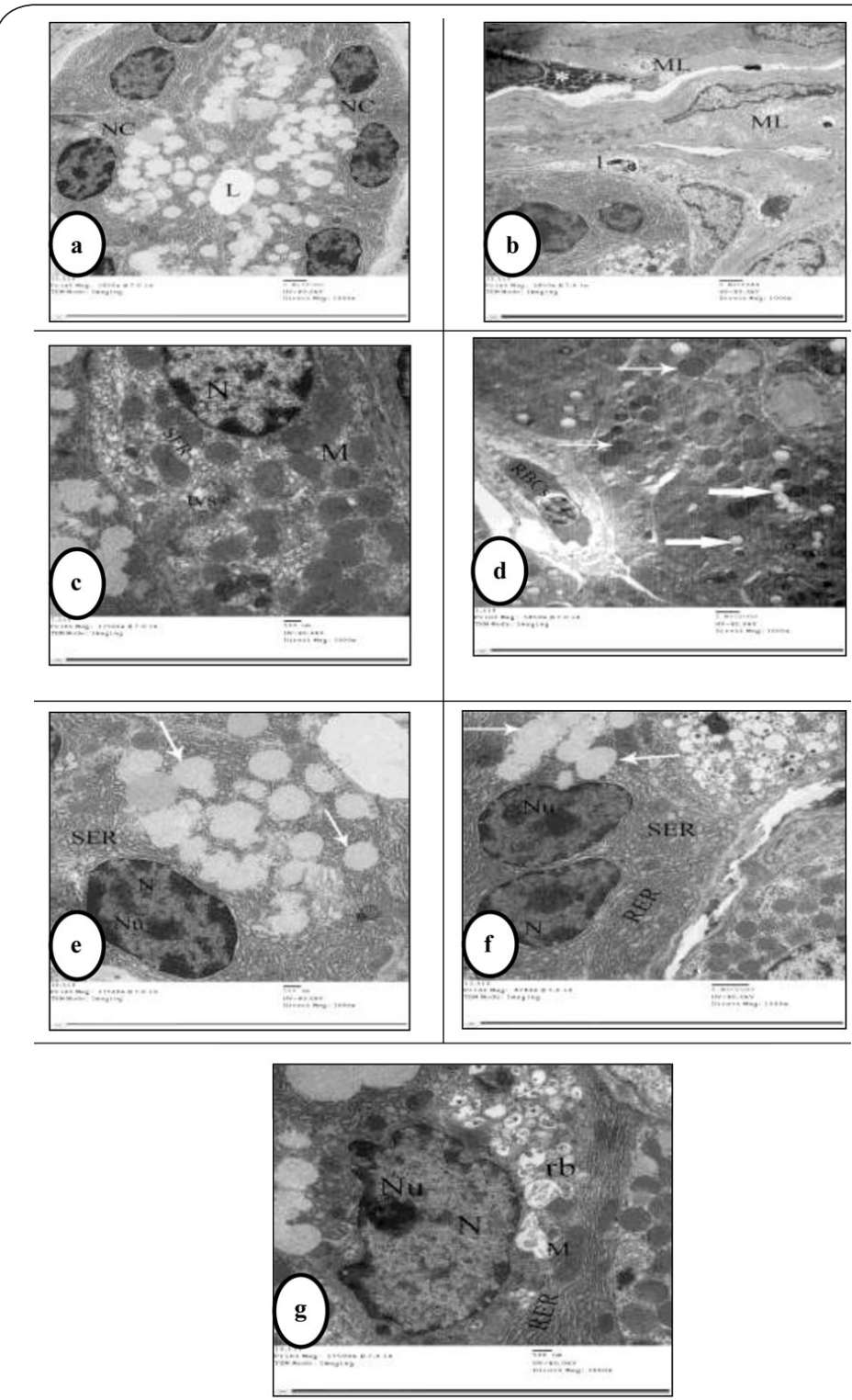

Figure 5(a-g): Electronmicrographs of the stomach of Clarias gariepinus $\mathbf{5 a}$ ) showing group of mucous neck cells with extensive masses of mucous secretions around the lumen (L). Figure 5b) showing enteroendocrine cell with electron dense granules of various morphologies (star), thick layer of muscle (ML), lymphatic vessel in submucosa layer (1). Figure 5c) showing oxyntic cell that exhibits heterogenous nucleus $(\mathrm{N})$, large number of oval and round mitochondria (M), smooth endoplasmic reticulum (SER) and extensive tubulovesicular system (tvs). Figure 5d) showing number of mucous neck cells with saturated (thick arrow) and unsaturated secretory granules (thin arrow) with presence of nucleated RBCs in sub-mucosa layer. Figure 5e) High magnification power of mucous neck cell showing nucleus $(\mathrm{N})$ with prominent nucleolus $(\mathrm{Nu})$, large number of smooth endoplasmic reticulum (SER) and large number of mucous granules (arrows). Figure 5f) Exhibits mucous binucleated cell with prominent nucleoli $(\mathrm{Nu})$, mucous granules and large number of rough endoplasmic reticulum (RER, smooth endoplasmic reticulum (SER) and mucous secretions (arrows). Figure 5g) Exhibits mucous cell with mucous granules, large nucleus $(\mathrm{N})$ with prominent nucleolus $(\mathrm{Nu})$, number of elongated mitochondria $(\mathrm{M})$, cisternae of rough endoplasmic reticulum (RER) and large number of residual bodies (rb). 
while the stomach of $O$. niloticus appered as s- shape and divided into cardiofundic and pyloric portions.

Histological examination of the stomach of African cat-fish confirmed that it is composed of three distinct regions: cardiac, fundic and pyloric; these results were reported in many teleosts and are agreement with that reported by [14-16].

The present microscopical results of the cardiac region of the African catfish stomach showed that the epithelial cells lining both the gastric mucosa and pits contain muco-substances or apical mucin. This result indicates the presence of only neutral glycoproteins which might be related to the conduction of food, may provide efficient protection against proteolysis and mechanical injury [17-18], and has buffering effects on high concentration acid contents of the stomach [19]. Moreover, it may also be involved in digestive activity by digestion and absorption of easily digested molecules, such as disaccharides and short-chain fatty acids [20].

These findings agree with that of [21] who found that mucins also regulate the $\mathrm{pH}$ of the gastric fluid, explaining the variations in the $\mathrm{pH}$ of the gastric fluid in different species with different diets. However, the neutral mucous serve as protection to stomach epithelium from auto-digestion caused by hydrochloric acid and enzymes secreted by gastric gland by forming an adherent mucus gel [6-22] and provides complementation for the degradation [2].

In this study, extensive collagenous fibers that noticed in the lamina propria form a supporting, protective and strengthened layer as well as keep the gland in its position. In addition, [1623-24] stated that powerful gastric muscles of carnivorous catfish containing well-developed inner circular and outer longitudinal unstriated muscle fibers and collagenic fibers of the submucosa may be involved in the involuntary contraction of food digestion, increasing the retention time of ingested food in the stomach and increasing the volumetric capacity of the stomach. Moreover, it may also be involved in trituration [25-26] and for supporting and strengthening since the stratum compactum is lacking in the species under investigation [27].

[28] described a pyloric region of the stomach with tubular glands, and [29] described an initial and terminal region with tubular glands, although they stated that the latter did not contain mucous cells. However, we found in O. nilotica that the region with tubular glands consisting of mucous cells was continuous from the entry of the oesophagus, across the anterior part of the stomach to the pyloric valve, essentially providing a bypass circumventing the sac-like portion of the stomach. Mucous secretion of the tubular glands would enable rough particles to pass along the tract easily and striated muscle would make voluntary regurgitation possible, as suggested by [28]. Passage of material into the intestine could be prevented by the pyloric valve.

Similarly, [21-29-30] recorded that the mucus cells in the tubular glands and the neck cells of the gastric glands probably protect the mucosa from the very acid contents of the stomach. Neck cells secreting acid sulphated carbohydrates were described in Oreochromis, According to [30] specialized neck cells have been found in only a few species of fish.

Ultrastructurally, [31,32] described features of both oxyntic and peptic cells of the mammalian stomach but recorded as oxynticopeptic cells of the cardiac region of the catfish stomach; the apical portion of the cytoplasm contains a welldeveloped vesiculotubular system with many mitochondria which may be involved in the secretion of hydrochloric acid. Moreover, these cells possess well-developed rough endoplasmic reticulum and numerous secretory granules which may be involved in the production of pepsinogen, on the other hand oxyntic cell of T. nilotica shows large nucleus, prominent nucleolus, large number of active mitochondria with prominent cristae; Note the abundance of tubules of tubulovascular system with extensive microvilli that extend into its lumen.

In this study, enteroendocrine cells appear with vesicular nuclei, rough endoplasmic reticulum, and characteristic secretory granules. These endocrine cells may be involved in the secretion of various hormones that play an important role in digestive activities of the gut [33-35]. Moreover, they secrete many hormones such as gastrin, somatostatin and serotonin which stimulate the glandular cells to increase hydrochloric acid secretion [36].

In addition, gastric musclosa of $O$. nilotica have thin layer of smooth un-striated muscle fibers; on the other hand, powerful gastric musclosa of carnivorous catfish containing welldeveloped inner circular and outer longitudinal unstriated muscle fibers and collagenic fibers of the submucosa involved in the involuntary contraction of food digestion, these results similar with observations studied by [16-24] increasing the retention time of ingested food in the stomach and increasing the volumetric capacity of the stomach [23].

\section{Competing interests}

The authors declare that they have no competing interests.

Authors' contributions

\begin{tabular}{|l|c|c|}
\hline Authors' contributions & MMME & EESEMEN \\
\hline Research concept and design & $\checkmark$ & $\checkmark$ \\
\hline Collection and/or assembly of data & $\checkmark$ & $\checkmark$ \\
\hline Data analysis and interpretation & $\checkmark$ & $\checkmark$ \\
\hline Writing the article & $\checkmark$ & $\checkmark$ \\
\hline Critical revision of the article & $\checkmark$ & $\checkmark$ \\
\hline Final approval of article & $\checkmark$ & $\checkmark$ \\
\hline Statistical analysis & $\checkmark$ & $\checkmark$ \\
\hline
\end{tabular}

\section{Publication history}

Editor: Giuseppe Musumeci, University of Catania, Italy. Received: 07-July-2019 Final Revised: 19-Aug-2019 Accepted: 22-Aug-2019 Published: 09-Sep-2019 


\section{References}

1. Cinar $\mathrm{K}$ and Senol N. Histological and histochemical characterization of the mucosa of the digestive tract in flower fish (Pseudophoxinus antalyae). Anat Histol Embryol. 2006; 35:147-51. | Article I PubMed

2. Anderson TA. Histological and cytological structure of the gastrointestinal tract of the luderick, Girella tricuspidata (pisces, kyphosidae), in relation to diet. J Morphol. 1986; 190:109-119. | Article I PubMed

3. Olsen $R$ and Ring $\varnothing$ E. Lipid digestibility in fish: A review. 1997.

4. Ring $\varnothing E$, Olsen R, M Mayhew T and Myklebust R. Electron microscopy of the intestinal microflora of fish. 2003.

5. de Melo Germano R, Regina Stabille S, de Britto Mari R, Pereira J, Raquel Scoz Faglioni J and Hubner de Miranda Neto M. Morphological characteristics of the Pterodoras granulosus digestive tube (Valenciennes, 1821) (Osteichthyes, Doradidae). 2014.

6. Smith L.S. Digestive functions in teleost fishes. In: Fish nutrition. 2nded. London: Academic Press. 1989; 331-421.

7. Reifel CW and Travill AA. Structure and carbohydrate histochemistry of the stomach in eight species of teleosts. J Morphol. 1978; 158:155-67. | Article | PubMed

8. De Graaf $G$ and Janssen $H$. Artificial reproduction and pond rearing of the African catfish Clarias gariepinus in Sub-Saharan Africa: a hanbook. FAO, Roma (Italia). 1996.

9. Moawad UK, Awaad AS and Tawfiek MG. Histomorphological, histochemical, and ultrastructural studies on the stomach of the adult African catfish (Clarias gariepinus). J Microsc Ultrastruct. 2017; 5:155166. | Article | PubMed Abstract | PubMed FullText

10. Bancroft J.D and Gamble M. Theory and practice of histology techniques. Churchill Livingstone Elsevier. 2008; 83-134.

11. Hernández D, Pérez Gianeselli M and Domitrovic H. Morphology, Histology and Histochemistry of the Digestive System of South American Catfish (Rhamdia quelen). Int J Morphol. 2009; 27:105-11.

12. Sis $R$, Ives $P$, Jones $D$, Lewis $D$ and Haensly $W$. The microscopic anatomy of the oesophagus, stomach and intestine of the channel catfish, Ictalurus punctatus. Journal of Fish Biology. 1979; 14:179-186.

13. Ezeasor D.N and Stokoe W.M. Light and electron microscopic studies on the absorptive cells of the intestine, caeca and rectum of the adult rainbow trout, Salmo gairdneri, Rich. Journal of Fish Biology. 1981; 18:527-544.

14. Ekele I, Nlebedum U, Okechukwu N and Isaiah A. The Stomach of the Adult African Catfish (Clarias gariepinus, Siluriformes: Clariidae) in Farm Conditions: A Morphological and Mucin Histochemistry Analysis. Rev FacCs Vets. 2014; 55:4-10.

15. Raji A.R and Norouzi E. Histological and histochemical study on the alimentary canal in Walking catfish (Claris batrachus) and piranha (Serrasalmus nattereri). Iranian Journal of Veterinary Research. 2010; 11:255-261. | Article

16. Xiong $D$, Zhang L, Yu H, Xie C, Kong Y, Zeng Y, Huo B and Liu Z. A study of morphology and histology of the alimentary tract of Glyptosternum maculatum (Sisoridae, Siluriformes). Acta Zoologica. 2011; 92:161-169. | Article

17. Petrinec Z, Nejedli S, Kuzir S and Opacak A. Mucosubstances of the digestive tract mucosa in northern pike (Esox lucius L.) and european catfish (Silurus glanis L.). Veterinarski arhiv. 2005; 75:317-327.

18. Awaad, Ashraf Sayed, Moawad, Usama Kamal, \& Tawfiek and Mohamed Gomaa. Comparative histomorphological and histochemical studies on the oesophagus of nile Tilapia Oreochromis niloticus and african catfish Clarias gariepinus. Journal of Histology. 2014; 987041. | Article

19. Kozaric Z, Kuzir S, Petrinec Z, Gjurcevic E and Baturina N. Histochemistry of complex glycoproteins in the digestive tract mucosa of Atlantic bluefin tuna (Thunnus thynnus L.). Veterinarski arhiv. 2007; 77:441- 452.

20. Grau A, Crespo S, Sarasquete M.C and de Canales M.L.G. The digestive tract of the amberjack Seriola dumerili, Risso: a light and scanning electron microscope study. Journal of Fish Biology. 1992; 41:287-303. | Article

21. Osman A and Caceci T. Histology of the stomach of Tilapia nilotica
(Linnaeus, 1758) from the River Nile. Journal of Fish Biology. 1991; 38:211-223. | Article

22. Ferraris R.P, Tan J.D and De La Cruz M.C. Development of the digestive tract of milkfish, Chanos chanos (Forsskal): Histology and histochemistry. Aquaculture. 1987; 61:241-257. | Article

23. Albrecht $M$, Ferreira $M$ and Caramaschi E. Anatomical features and histology of the digestive tract of two related neotropical omnivorous fishes (Characiformes; Anostomidae). Journal of Fish Biology. 2001; 58:419-430. | Article

24. Diaz AO, Garcia AM, Figueroa DE and Goldemberg AL. The mucosa of the digestive tract in Micropogonias furnieri: a light and electron microscope approach. Anat Histol Embryol. 2008; 37:251-6. I Article I PubMed

25. Cao XJ and Wang WM. Histology and mucin histochemistry of the digestive tract of yellow catfish, Pelteobagrus fulvidraco. Anat Histol Embryol. 2009; 38:254-61. | Article | PubMed

26. Garrido M.O, Oller C.G and Equisoain M.A. Effect of diet on gastric mucosa cells in the European eel (Anguilla anguilla L.). Histochemical and ultrastructural study. Micron. 1996; 27:25-34. | Article

27. Burnstock $G$. The morphology of the gut of the brown trout (Salmo trutta). Journal of Cell Science. 1959; 3: 183-198. I Article

28. Al-Hussaini A. On the functional morphology of the alimentary tract of some omnivorous teleost fish. Egyptian academy of Science. 1953.

29. Caceci T, El-Habback H,Smith S and Smith B. The stomach of Oreochromis niloticus has three regions. Journal of Fish Biology. 1997; 50:939-952. | Article

30. Gargiulo AM, Ceccarelli P, Dall'aglio C and Pedini V. Ultrastructural study on the stomach of Tilapia spp (Teleostei). Anat Histol Embryol. 1997; 26:331-6. | Article | PubMed

31. Gallagher M.L, Luczkovich J.J and Stellwag E.J. Characterization of the ultrastructure of the gastrointestinal tract mucosa, stomach contents and liver enzyme activity of the pinfish during development. Journal of Fish Biology. 2001; 58:1704-1713. | Article

32. Garrido M.O, Torres M.N and Equisoain M.A. Histological, histochemical and ultrastructural analysis of the gastric mucosa in Oncorhynchus mykiss. Aquaculture. 1993; 115:121-132. | Article

33. Khidr B. Electron microscopic studies on the intestinal mucosa of the Nile catfish, Chrysiehthys auratus (Geoffroy) with special interest in its absorptive function. Egypt J Zool. 2006; 47:143-165.

34. Lee J, Ku S, Park K and Lee H. Immunohistochemical study of the gastrointestinal endocrine cells in the Korean aucha perch. Journal of Fish Biology. 2004; 65:170-181. | Article

35. Podkowa D and Goniakowska-Witalinska L. Morphology of the airbreathing stomach of the catfish Hypostomus plecostomus. J Morphol. 2003; 257:147-63. | Article | PubMed

36. Ghattas S. A histological study on the digestive tract of eel (Anguilla Anguilla L.) with special reference to ultrastructure of gastric glandular cells. J Mansoura Vet Med Anost Fish Biol. 2004; 58:419-430.

\section{Citation:}

Elwan MMM and El Nahass EESM. Comparitive histological and ultrastructural studies on the stomach of African cat fish (Clarias gariepinus) and (Oreochromis niloticus). J Histol Histopathol. 2019; 6:3. http://dx.doi.org/10.7243/2055-091X-6-3 